\title{
WHEN PRIME DEPOSITORS RUN ON THE BANKS: A BEHAVIORAL APPROACH
}

\author{
Natanael Waraney Gerald Massie* and Chaikal Nuryakin ${ }^{* *}$ \\ "Universitas Indonesia. Email:, natanael.waraney@ui.ac.id \\ "* Corresponding author. Department of Economics, Faculty of Economics and Business, Universitas \\ Indonesia. Email: chaikal.nuryakin@ui.ac.id
}

\begin{abstract}
This paper examines the effect of two psychological attributes, namely an individual's risk and time preference, on withdrawal decisions. Our sample is a pool of prime depositors in Indonesia, mainly due to the country's deposit market being heavily concentrated on such depositors. We find that most of the prime depositors are risk averse long-term depositors. The regression results show that there is a significant correlation between the decision to withdraw and individual risk and time preference in most economic shock scenarios. The study concludes that a bank-run could happen if the rupiah depreciates by approximately $27 \%$ (from $\mathrm{Rp} 13,436$ to $\mathrm{Rp} 17,000$ ) and when there is a medium or a large bank failure.
\end{abstract}

Keywords: Withdrawal decision; Time preference; Risk preference; Bank run; Prime depositors. JEL Classification: D81; G02; G21.

\author{
Article history: \\ Received : September 10, 2018 \\ Revised : November 02, 2018 \\ Accepted : March 03, 2019 \\ Available online : February 29, 2020 \\ https://doi.org/10.21098/bemp.v23i1.954
}




\section{INTRODUCTION}

While previous studies on bank runs and financial insolvency are primarily based on macroeconomic and theoretical approaches, the behavior of economic agents, particularly their risk and time preferences, has not been much explored. At the individual level, however, the role of the two behavioral aspects is very prominent during decision-making situations. Individuals with different risk preferences make different decisions under uncertainty (Gneezy and Potters, 1997; Powell and Ansic, 1997; Charness and Gneezy, 2012). Similarly, individuals with different time preferences make different decisions weighing up future benefits (Khwaja et al, 2007; Burks et al, 2012).

We argue that decisions on whether to withdraw money from respective banks under financial shocks yield similar tradeoffs for depositors. They would judge whether the situation is too risky or not, and whether future benefits outweigh present benefits if they withdraw now compare to later. With this set up, depositors would jointly determine the insolvency situation in idiosyncratic cases.

Indonesia depicts a rather interesting case regarding depositors. Table 1 and 2 show the concentration of deposit market. Table 3 shows characteristics of depositors. In Table 1, it can be noted that the commercial banking system is dominated by four biggest banks (classified as BUKU 4 banks) whose total share is 49 percent $(\mathrm{OJK}, 2015)$. To put this into a proper perspective, just above fifty percent of the remaining market share is competed by the rest of the market (OJK, 2015). It is also very interesting to know that a staggering 70.6 percent of the total fund in the banking system is owned by only 0.57 percent of all depositors (Nuryakin and Massie, 2018). We call them the prime depositors, and these are mostly individuals with deposit of Rp500 million (approximately US\$37,500) or more.

Table 1.

Concentration of Deposit Market in Indonesia (All Banks), December 2015

This table has information on the concentration of deposit market in Indonesia. Deposit nominal values are reported against number of accounts (and proportion) and savings (in currency value terms and proportion). Finally, ${ }^{*}$ denotes 500 million rupiah is the threshold for prime depositor classification and ${ }^{* *}$ denotes 2 billion rupiah is the maximum insured deposit amount.

\begin{tabular}{lcccc}
\hline \multirow{2}{*}{ Nominal (in Rupiah) } & \multicolumn{2}{c}{ Number of Accounts } & \multicolumn{2}{c}{ Saving } \\
\cline { 2 - 5 } & Number & Percent & (IDR Trillion) & Percent \\
\hline Up to 100 Million & $171,486,517$ & 97.71 & 668.16 & 14.93 \\
$>100 \mathrm{M} \mathrm{s} /$ d 200 M & $1,809,429$ & 1.03 & 253.98 & 5.68 \\
> 200 M s/d 500 M & $1,221,578$ & 0.70 & 393.94 & 8.81 \\
> 500 M s/d 1 Billion & 500,738 & 0.29 & 369.85 & 8.27 \\
>1 B s/d 2 B** & 252,082 & 0.14 & 359.36 & 8.03 \\
> 2 B s/d 5 B & 150,446 & 0.09 & 467.87 & 10.46 \\
> 5 B & 81,126 & 0.05 & $1,960.64$ & 43.83 \\
& $175,501,916$ & 100 & $4,473.77$ & 100 \\
\hline
\end{tabular}

Source: Nuryakin and Massie (2018); Indonesia Deposit Insurance Company (LPS).

Based on this information, we argue that policymakers and researchers should pay more attention to the behavior of prime depositors. With this argument, our study focuses on estimating the time and risk preferences of the prime depositors in Indonesia and examining whether they influence withdrawal decisions under 
financial shocks. By eliciting these two behavioral attributes of depositors, we provide a better picture regarding the vulnerability of the Indonesian banking system to bank runs.

Intuitively, if prime depositors are risk-averse then a small shock to the economy would lead them to withdraw their deposits. Under normal conditions, prime depositors with different time preferences will have different pattern of withdrawals. However, it is obvious that when many of these individuals decide to withdraw, then, a bank run will potentially occur, and this is the hypothesis of our paper.

Empirically, we can predict the insolvency of a bank two years earlier. As pointed by Jordan (2000), when uninsured depositors start to cash out, the bank will start to crumble about two years before it eventually become insolvent. For the Indonesian case, the limit of deposit insurance is Rp2 billion (approximately US\$150,000), meaning that depositors are technically uninsured.

Therefore, it is interesting that very few studies are available on the behavior of prime depositors. One reason could be the difficulty of collecting the data. This could explain why the few existing studies mostly use experimental methods; see for example, Dijk (2017), Kiss, Rodriguez-Lara, and Rosa-Garcia (2018), and Schotter and Yorulmazer (2009).

We hypothesize that time and risk preferences of prime depositors affect withdrawal decisions, which, in turn, determines the occurrence of bank runs. To test our hypothesis, we interviewed 33 prime depositors based on predefined questionnaire (perception and real data). We utilize a logistic regression model to analyze the effect of time and risk preferences on the decision to withdraw.

We find that prime depositors in Indonesia tend to maintain their deposits in banks over a longer period (i.e. they are long-term depositors). On the alarming side, most of the depositors are risk averse, and, hence, are sensitive to the shocks. We show that the risk and time preferences significantly affect withdrawal decisions. On the one hand, demonstration effect or information cascade will create bank runs. On the other hand, the small bank failure or Rupiah depreciation to Rp15,000 per USD will not create bank runs.

Our paper differs from existing ones in several aspects. First, we examine the real market players (prime depositors), while studies such as Dijk (2017) and Schotter and Yorulmazer (2009) considered university students, and Kiss, Rodriguez-Lara and Rosa-Garcia (2018) focused on the general public. Second, we examined withdrawal decisions under different hypothesized scenarios, while existing studies examined withdrawal decisions under different emotional priming (see, for example, Dijk (2017).

The next section reviews the literature. Section III discusses the data and methodology, while Section IV presents the results. Section V presents the conclusion.

\section{LITERATURE REVIEW}

\section{A. Diamond and Dyvbig Model}

Our study is inspired by the theoretical framework developed by Diamond and Dyvbig (1983), commonly shortened as D\&D model. To be specific, we employed the modified D\&D model presented in Goldstein and Pauzner (2005). 
The setup of the model assumes three periods in the economy. At the current period $(t=0)$, all depositors choose the bank as their respective endowments. Period $1(t=1)$ is the time in the near future, while period $2(t=2)$ would be a time in the longer horizon. There are two agents involved: the bank's customers and the bank itself. Each bank is in autarkic state or is independent.

Banks offer risk sharing to the customer-that is, a demand-deposit contract and longer-term loans altogether, and contracts for their customers. The former serves as liquid liabilities, while the latter acts as an illiquid asset. This puts the bank into a condition, in which they have to pay any withdrawals of demanddeposit contract anytime the customers want to. Furthermore, banks cannot ask for the loans' repayments as if the loans have longer maturity or because the customers cannot repay the loans immediately. In normal circumstances, this set up is normal as the withdrawals are stochastic and relatively insignificant compared to the ready-to-use reserves of the banks.

Bank customers are classified into two types, namely patient customers, and impatient customers. The impatient customers will withdraw in the short time $(\mathrm{t}=1)$ due to liquidity shocks. On the contrary, the patient customers will wait until the maturity of their deposits, hence, opting to withdraw in the distant future $(t=2)$. When there are changes in the fundamentals, the patient customers could also withdraw at $t=1$. The proportion of the impatient customers is $\lambda$, and the proportion of the patient customers is $\rho=(1-\lambda)$ such that:

$$
\lambda+\rho=1
$$

Bank customers can withdraw their money anytime. The utility function of the whole population would then be:

$$
u_{\text {total }}=\lambda u\left(c_{1}\right)+\rho u\left(\frac{1-\lambda c_{1}}{1-\lambda} R\right) E_{\theta}[p(\theta)]
$$

Equation (2) shows that the total welfare of the society would be equal to the utility gained by the impatient customers (i.e. first term on the right-hand side) plus the utility of the patient customers (i.e. second term). $\theta$ represents the possibility of the economy failing. Similarly, the inverse or complementary probability of $\theta=p^{c}(\theta)=1-p(\theta)$ represents the probability of bank runs. Empirically, $p(\theta)$ is hardly known.

Recall that Equation (2) resembles the total welfare of the economy in terms of inter-temporal withdrawals. Focusing on first period, we have:

$$
u_{1}=\lambda u\left(c_{1}\right)
$$

We need to modify Equation (3) to accommodate the patient customers who decide to withdraw in the first period:

$$
u_{1}=\left(\lambda+\left(n\left(\theta^{*}, \theta^{\prime}\right)-\lambda\right)\right) \cdot u\left(c_{1}\right)
$$


Equation (4) shows that a proportion of $(n-\lambda)$ were initially patient customers $(\rho)$ but consumes in period 1 , where $n$ is the actual proportion of people withdrawing. We can rewrite the equation as:

$$
u_{1}=n u\left(c_{1}\right)
$$

Equation (5) replaces $\lambda$ with $n$, indicating that the proportion of withdrawers could be bigger than the impatient customers (added by the patient customers).

In the Diamond and Dyvbig (1983) model, there could be a case of multiple equilibria; the 'good' and the 'bad' equilibria. For the 'good' equilibrium, only impatient customers (faced with liquidity shocks) will withdraw in the first period (as much as $\lambda$ ). The equilibrium is good for the economy, since only stochastic and insignificant withdrawals occur and banks have enough reserves to pay.

In the 'bad' equilibrium, the patient customers also withdraw in the first period. In this case, the patient customers will withdraw, as the impatient customers withdraw. This sparks the sense of panic within the patient customers, every other patient customer also withdraws, which leaves the banks with no money.

Following Goldstein and Pauzner (2005) and Morris and Shin (2001), it is possible for the equilibrium to lie between the two extreme scenarios (good and bad). To model this, one can introduce a threshold level of $\theta$ (or $\theta^{*}$ ) and perceived level of $\theta$ (or $\theta^{\prime}$ ), which will be the signal for the customer to make decision.

Previous studies did suggest that this perceived level is virtually possible to be calculated or predicted (Allen and Gale, 1998; Goldstein and Pauzner, 2005). In this paper, we take the advantage of this possibility by directly analyzing the behavior of depositors, setting up scenarios to infer $\theta^{*}$ and $\theta^{\prime}$ (withdrawal decisions), and, then, examining how the time and risk preferences, amount of deposit, and other variables affect these withdrawal decisions.

\section{B. On Bank Run}

A bank run occurs when a large number of withdrawals are made at the same time or in a very narrow time window and is significant enough to make one bank collapse. The impact of the withdrawals depends on the number of people withdrawing and the amount of withdrawals. Generally, the withdrawals are due to widespread concerns regarding the performance of related banks and/ or the prevailing economic condition in the country. As one bank collapses, the possibility of contagion emerges, paving the way for financial crisis in the country (Brown, Trautmann, \& Vlahu, 2014).

Diamond and Dybvig (1983) defined bank run as one of the 'almost everpresent phenomena' in the history of monetary crisis around the world. They highlighted that as depositors rush to withdraw their money, banks alike would find themselves in a 'bank panic' position, where they might be forced to fund the return of these deposits by selling their assets, notably for a much lower amount compared to the normal market price. The 1939 Great Depression in the United States is one example of crises predominantly caused by this phenomenon. 
Regarding this matter, Iyer and Puri (2013) stressed the importance of an adequate relationship between depositors and banks. By keeping good relationship with depositors, banks can prevent bank runs. In this paper, we argue that this strategy needs to consider the time and risk preferences of the depositors.

This argument was amplified by Brown, Guin, and Morkoetter (2014), who, in addition to these factors, identified the role played by switching cost across banks in withdrawal decisions. Brown, Guin, and Morkoetter (2014) found that there is a high propensity for a household to make withdrawals when their bank is under distress. Iyer and Puri (2013) also explained that empirically only a moderate number of depositors would come back and redeposit their money into their respective banks after cases of bank runs. This implies that bank runs are not a short-term problem as they are accompanied by several adverse effects.

It is widely accepted that bank runs are linked to adverse information in the banking system (Schumacher, 2000). They may also be caused by panic among the depositors (Chen and Hasan, 2008). In large-scale bank runs, depositors do not care if their money is deposited in a 'good' or 'bad' banks; they simply withdraw all their money.

Recent theoretical works on the subject are extensions of Diamond and Dybvig's (1983) model. Andolfatto, Nosal, and Sultanum (2017) proposed a theoretical model extending the Diamond and Dybvig model allowing depositors to 'circulate rumor' and investigated the possible equilibrium. On the banking system's side, Kashyap, Tsomocos, and Vardoulakis (2017) made alterations that allow banks to choose between liquid and illiquid assets, and also between deposits and equity. Closely related to bank runs, Ely (2017) introduced dynamic persuasion mechanisms between principals and agents.

Some policies are then proposed to counter the state. Deposit insurance, for example, was proven to be an effective strategy to hold depositors from cashing out their money (Schotter and Yorulmazer, 2009). The result was alarming for Indonesia because the deposit market is highly concentrated on the prime depositors.

Related to deposit insurances, Bijlsma and van der Wiel (2012) studied whether a better awareness of deposit insurance affect the withdrawal behavior of households. Bijlsma and van der Wiel (2012) found that the increased awareness has virtually no effect on households' behavior. Schotter and Yorulmazer (2009) also tested another policy in their work-providing better information to depositors about the condition of the banking system. The result is that the more symmetric information provided by the banking system, the less likely depositors make a rush decision. Those without information also tend to wait for the first movers to withdraw their money, then simultaneous withdrawals occur. This is also alarming for Indonesia because the country has low financial literacy, and, hence, information flow is virtually symmetric.

Another group of studies utilize macroeconomic models and analyze whether monetary policies can help counter the state of the crisis; see among others Pathan, Skully, and Wickramanayake (2008) or Choe and Lee (2003).

More recent studies on bank runs incorporate behavioral aspects of depositors. Kiss, Rodriguez-Lara, and Rosa-Garcia (2018) suggest that even with adequate fundamentals and coordination among depositors, depositors will still panic 
and make excessive withdrawals leading to bank runs. Furthermore, depositors generally overestimate the occurrence of bank run. Using experimental approach, Dijk (2017) conclude that withdrawal decisions are significantly affected by the inducement of background emotional states, such as fear, sadness, and happiness.

What makes our paper different from these studies is that we are relaxing the macroeconomic model assumption and incorporating psychological aspects of depositors. We explain this in section III.

\section{Individual Risk and Time Preferences}

Dijk (2017) explored the role of psychological factors in withdrawal decisions using emotional priming. Likewise, Kiss, Rodriguez-Lara, and Rosa-Garcia (2018) analyze whether risk aversion, loss aversion, and other behavioral characteristics are correlated with withdrawal decisions. We explore the role of risk and time preferences in withdrawal decisions. We define risk preferences as the variation of individuals' preferences across different risks. Conversely, we define time preferences as the way depositors make decisions between taking gains (or losses) now or at some point of time in the future.

In terms of risk preferences, depositors could be classified into risk averse, risk neutral, and risk lovers. Similarly, with regard to time preferences, depositors can be classified into patient and impatient depositors. The latter depositors prefer longer interval decisions. Time and risk preferences are negatively correlated. Inevitably, longer time yields higher uncertainty, hence higher risk, showing the inverse relationship between the two; see the works of Andreoni and Sprenger (2009), and Anderhub, Gueth, Gneezy, Sonsino (2001).

\section{METHODOLOGY}

We interviewed a pool of 33 prime depositors (i.e. $N=33$ ). To be included in our sample, respondents must hold more than Rp500 million in their bank accounts; the 33 prime depositors met this criterion. We managed to gather primary information on their individual microeconomic attributes, such as withdrawal decisions under certain scenarios, risk and time preferences, and their plans on withdrawing the deposits in the near or distant future, along with demographic characteristics.

Based on the amount of deposits, the number of depositors holding Rp1 to Rp2 billion dominated the sample, consisting of about 67 percent of the total respondents. Depositors with up to Rp500 million to Rp1 billion are 24,24 percent of the sample, while a modest 9,09 percent of the sampled depositors had more than Rp2 billion, and rounds up the sample. 
Table 2.

\section{Amount of Savings Distribution Between Respondents}

This table reports the amount of savings distributed between respondents based on the amount classification notes in column 1.

\begin{tabular}{lcc}
\hline Amount of Savings & $N$ & Percentage \\
\hline Rp 500 million to Rp 1 billion & 8 & $24,24 \%$ \\
Rp 1 billion to Rp 2 billion & 22 & $66,67 \%$ \\
More than Rp 2 billion & 3 & $9,09 \%$ \\
\hline
\end{tabular}

A. Economic Model

We use the following logistic regression model:

$$
\ln \left[\frac{P_{k}}{1-P_{k}}\right]=b_{1} X_{1}+b_{2} X_{2}+b_{3} X_{3}+\ldots+b_{n} X_{n}
$$

where $P_{k}$ denotes the probability that an individual withdraws his money from the bank under scenarios $k$, and $X_{i}$ denotes the included demographic, microeconomic behavior, and other relevant regressors.

\section{B. Time and Risk Preference Elicitation}

To elicit time and risk preferences, we utilized pre-defined questionnaire for the in-depth interviews, and this questionnaire is adapted from previous studies such as Meier and Sprenger (2010) and Eckel and Grossman (2002). We extract two variables from the interviews: $X$, smaller payoff in nearer future, and $Y$, bigger payoff in a more distant future. We, then, compute the individual discount factors by dividing $X$ by $Y(X / Y)$ using scalable switching points between the near and distant future choices. This method is adapted from the study by Meier and Sprenger (2010).

To obtain the risk preferences, we used the method developed by Eckel and Grossman (2002), which entails asking our respondents to choose from six different low-high payoff choices. Each choice would suggest the nature of their risk preferences, and would also lie within the Constant Relative Risk Averse (CRRA) range (Charness, Gneezy, Imas, 2013). We, then, take the average between the lowest and highest implied CRRA to quantify the risk preferences.

For robustness check, we elicited three individual discount factors from different time ranges, and, then, we take their averages to calculate the time preferences. Another robustness check regarding risk preferences is by comparing respondents' answers on investment opportunities with various success probabilities (predetermined). To infer the $\theta^{*}$ and $\theta^{\prime}$ (withdrawal decisions), and time and risk preferences more accurately, we set up four scenarios: (1) Rupiah weakening, (2) small bank failing, (3) own bank failing, and (4) a massive capital outflow from the country. 


\section{Cascade Effect under Different Scenarios}

It is logical to set the withdrawal decision of someone affected by peers or someone else. In this paper, we calculate and internalize this 'cascade effect,' or peer withdrawal effect, that might occur during an economic shock situation leading to a possibility of a bank run.

We asked respondents whether or not they will withdraw their deposits if they notice a certain percentage of other depositors withdrawing. In the simulation exercise, we took the percentage of respondents who answered that they would withdraw in the very first signs of an economic shock (from first analysis); then, we checked the threshold percentage of those claiming to not pull out under this shock, and compare the percentage with the former. We did the simulations for any additional necessary rounds until it was evident that all depositors eventually withdrew their deposits.

\section{RESULT AND ANALYSIS}

\section{A. Respondents' Risk and Withdrawal Preferences}

We find that 9 out of the 33 depositors claim to withdraw at near future $t=1$ (classified as Type-1). We set a time frame of one year or less as the threshold classifying either type. The rest claim to withdraw in a longer time horizon $(t=2)$. In proportion, the number of people claiming to withdraw in the shorter horizon is low (i.e. $27.27 \%$ ). But recalling these people are prime depositors, withdrawing their money could have severe implications on bank's solvency in Indonesia.

During the identification, we found that most prime depositors are risk averse. This is an alarming condition since risk-averse people tend to avoid uncertainty. When faced with uncertainty in the economy, these risk-averse people could withdraw their money from banks. We find that 24 out of the 33 prime depositors are self-admittedly long-term depositors, where the risk preferences are of concern.

Table 3.

\section{Characteristics of Depositors}

This tables notes depositors' characteristics. Type-1 category of depositors is those who will withdraw in the near future. Type-2 represents depositors who will withdraw over a longer time horizon. This classification is based on a pre-determined questionnaire that we use for in-depth interviews, as explained in Section III.

\begin{tabular}{llccc}
\hline \multirow{2}{*}{ Description } & & \multicolumn{3}{c}{ Type of Depositors } \\
\cline { 3 - 5 } & Risk Averse & Type $\mathbf{1}$ & Type 2 & Total \\
\hline \multirow{3}{*}{ Risk Preferences } & 8 & 19 & 25 \\
& Risk Neutral & 0 & 4 & 4 \\
& Risk Lovers & 1 & 1 & 2 \\
& Total & 9 & 24 & 33 \\
\hline
\end{tabular}


Table 4.

Amount of Deposit across Risk Preferences

This table reports the amount of deposits across risk preferences. We used a pre-determined questionnaire during the in-depth interviews to quantify and categorize the risk preference of prime depositors. The threshold for deposit amount of IDR 2 billion refers the maximum deposit covered by Indonesia Deposit Insurance Company (LPS) for each account.

\begin{tabular}{lcccc}
\hline Description & Risk-averse & Risk neutral & Risk lovers & Total \\
\hline Rp 500 million - Rp 1 billion & 7 & 1 & 0 & 8 \\
Rp 1 billion - Rp 2 billion & 18 & 2 & 2 & 22 \\
$>$ Rp 2 billion & 2 & 1 & 0 & 3 \\
\hline Total & 27 & 4 & 2 & 33 \\
\hline
\end{tabular}

\section{B. Risk and Time Preferences under Different Scenarios}

The results of the logistic regression are reported in Table 5. On big bank failing scenarios (see Table 5), we found a statistically significant relationship between withdrawal decisions and risk preferences $(z=1.83 ; p=0.067)$. The result implies a more risk averse prime depositor is more likely to withdraw under this scenario.

Table 5.

\section{Estimated Coefficients under Different Scenarios}

This table reports results. The dependent is withdrawal decision. We use the logistic regression to estimate the odd ratio (OR). The coefficient is therefore the log odd ratio with the possible value range from $-\infty$ to $\infty$. The negative value indicates $O R \in[0,1]$, showing lower odds compared to the reference one. Time preference = individual discount factor. Finally, ${ }^{*}{ }^{* *}$, and ${ }^{* * *}$ represent $p<0.1, p<0.05$ and $p<0.01$, respectively.

\begin{tabular}{lcccc}
\hline $\begin{array}{l}\text { Withdrawal under } \\
\text { Certain Scenarios }\end{array}$ & $\begin{array}{c}\text { Extreme } \\
\text { Weakening of } \\
\text { Rupiah }\end{array}$ & $\begin{array}{c}\text { One Big } \\
\text { Bank Failure }\end{array}$ & $\begin{array}{c}\text { Massive } \\
\text { Capital } \\
\text { Outflow }\end{array}$ & $\begin{array}{c}\text { 50\% Chance Own } \\
\text { Bank Failing }\end{array}$ \\
\hline Risk Preferences & $1.44^{* *}$ & $12.76^{*}$ & $1.13^{* * *}$ & $-1.88^{* *}$ \\
Time Preferences & $11.29^{*}$ & 1.41 & $1.52^{* *}$ & 0.58 \\
Log of Amount of & 1.24 & 2.065 & $7.24^{* * *}$ & $38.845^{*}$ \\
$\begin{array}{l}\text { Savings } \\
\text { Constant }\end{array}$ & -34.84 & -30.82 & $-38.55^{* * *}$ & -28.96 \\
\hline
\end{tabular}

We found similar results in the case of extreme weakening of the Rupiah. The risk preference $(z=2.18 ; p=0.029)$ and time preference $(z=1.72 ; p=0.085)$ are positively associated with withdrawal decisions. In this scenario, the more risk-averse the depositors, the more likely they will withdraw. Furthermore, even the patient depositors (the ones with larger time preferences) will also withdraw when the Rupiah largely depreciates against other currencies (USD in this case).

Under $50 \%$ chance of own bank failing, risk preference is found to be significant (i.e. $z=-2.10 ; p=0.036) .^{1}$ The finding, in this case, is different from the other scenarios as the less risk-averse depositors are the ones more likely to withdraw when own bank is failing. The amount of savings is also significant suggesting that prime depositors with more deposits are likelier to withdraw $(z=1.78 ; p=0.075)$. This is logical as a higher amount of money is at stake under the scenario.

1 Negative log odd ratio (-2.1) shows that the odds of the risk averse depositors are lower than the odds of the reference category (risk lover). 
In our last scenario, all our variables of interest are significant. Risk preference $(z=2.24 ; p=0.025)$ and time preferences $(z=2.18 ; p=0.030)$, along with the amount of savings $(z=1.91 ; p=0.056)$, show a strong relationship with withdrawal decisions. More risk averse and patient prime depositors are again found to be likelier to withdraw under the shock. Prime depositors with a higher amount of savings are also implied to make a similar decision.

\section{Cascade Effect under Different Scenarios}

We simulate the cascade effect under various economic scenarios and report these results in Table 6. The severity of one small bank failing and the Rupiah exceeding Rp15,000/USD has moderate to no cascade effect. This means the shock would not lead to a bank run. In contrast, cascade effect is evident in the other 3 scenarios (1 big bank fail, 1 government bank fail, and the Rupiah highly depreciate from Rp17,000 to Rp20,000 per USD).

Table 6.

\section{Cascade Effect on Bank Run's across Certain Idiosyncratic Scenarios}

This table reports cascade effects on bank runs across certain idiosyncratic scenarios. The scenarios are reported in column 1 , verdict appears in column 2 , and the percentage of withdrawal is noted in the $3^{\text {rd }}$ column.

\begin{tabular}{lccc}
\hline Case & Verdict & Percent of Withdrawal & Time \\
\hline 1 Small Bank fails & No Run & $6.06 \%$ withdrawal (at most) & - \\
1 Big Bank fails & Run & $54.54 \% ; 93.93 \% ; 100 \%$ & 3 rounds \\
1 BUMN Bank fails & Run & $84.84 \% ; 100 \%$ & 2 rounds \\
Rupiah to Rp15,000/USD & No Run & $18,18 \%$ withdrawal (at most) & - \\
Rupiah to Rp17,000/USD & Run & $48.49 \% ; 75.76 \% ; 100 \%$ & 3 rounds \\
Rupiah to Rp20,000/USD & Run & $54.54 \% ; 87.88 \% ; 100 \%$ & 3 rounds \\
\hline
\end{tabular}

Putting the results together, we found that risk and time preferences alongside the amount of savings are important determinants of withdrawal decisions, and, in turn, bank runs. We expect that our findings would spur further experimental research in the long-running literature of bank runs (see Chen \& Hasan, 2008; Diamond \& Dybvig, 1983), along with those discussing the role of risk and time preferences on economic decisions (see Arrow, 1965; Frederick, Loewenstein, \& O'Donoghue, 2002; Friend, 1977). Aside providing trivial evidence about the presence of "bad-equilibrium", we also show how bad noises and signals affect the possibility of bank runs (see Goldstein and Pauzner, 2005). Regarding the behavioral aspects, our results suggest that risk and time preferences matter for withdrawal decisions.

\section{CONCLUSION}

This paper analyzes the effect of risk and time preferences, and the amount of saving on withdrawal decisions, and, in turn, the probability of bank runs. Using direct in-depth interviews with prime depositors in Indonesia, we unravel three interesting findings. First, prime depositors and make long-term withdrawal 
decisions. Second, prime depositors are risk averse, and are thus likely to withdraw their money under duress conditions. Third, risk and time preferences significantly affect the withdrawal decisions of prime depositors.

These findings should be considered by policymakers, particularly the Bank Indonesia, Otoritas Jasa Keuangan (OJK), Lembaga Penjamin Simpanan (LPS), and the Ministry of Finance. We encourage policymakers to use our model when assessing the banking system's susceptibility to bank runs.

Finally, our findings should be interpreted by taking into consideration our small sample size. We argue that future studies should seek to expand our sample in order to better understand the dynamics of bank runs in Indonesia. Indonesia relies heavily on prime depositors, and as such these depositors would be virtually available to be interviewed nationwide. Thus, national scale surveys should seek to cover these depositors.

Acknowledgement: We are grateful to Kajian Perekonomian dan Pembangunan Indonesia (Kanopi), for the relentless support during the preparation of the manuscript, especially the research division, with whom the study was collectively conducted. We thank, among others, Pyan Amin, Edith Zheng, Edo Setyadi, Fransiska Herline, Faris Maulana, Clifert Walandouw, Khaira Abdillah, Ghany Ellantia, Felicia Faustine, Amalia Cesarina, Abraham Pardede, Cyntia Suryadewi, 'Je' Aditya, and Daniera Nanda for their enormous contribution to the manuscript. The authors greatly appreciate the editor's comments, which vastly improved the paper, particularly Sections I and II.

\section{REFERENCES}

Allen, F., and Gale, D. (1998). Optimal Financial Crises. The Journal of Finance, 53, 1245-1284.

Anderhub, V., Güth, W., Gneezy, U., and Sonsino, D. (2001). On the Interaction of Risk and Time Preferences: An Experimental Study. German Economic Review, 2, 239-253.

Andolfatto, D., Nosal, E., and Sultanum, B. (2017). Preventing Bank Runs. Theoretical Economics, 12, 1003-1028.

Arrow, K. J. (1965). Aspects of the Theory of Risk-Bearing. Yrjö Jahnssonin Säätiö.

Bijlsma, M.J., and Wiel, K.M. (2012). What Awareness?: Consumer Perception of

Bank Risk and Deposit Insurance. CPB Netherlands Bureau for Economic Policy Analysis.

Brown, M., Guin, B., and Morkoetter, S. (2014). Deposit Withdrawals from Distressed Commercial Banks, University of St. Gallen, School of Finance Research Paper.

Brown, M., Trautmann, S., and Vlahu, R. (2014). Exploring the Transmission Channels of Contagious Bank Runs. Campos.

Burks, S., Carpenter, J., Götte, L., and Rustichini, A. (2012). Which Measures of Time Preference Best Predict Outcomes: Evidence from a Large-Scale Field Experiment. Journal of Economic Behavior E Organization, 84, 308-320. 
Charness, G., and Gneezy, U. (2012). Strong Evidence for Gender Differences in Risk Taking. Journal of Economic Behavior E Organization, 83, 50-58.

Charness, G., Gneezy, U., and Imas, A. (2013). Experimental Methods: Eliciting Risk Preferences. Journal of Economic Behavior E Organization, 87, 43-51.

Chen, Y., and Hasan, I. (2008). Why Do Bank Runs Look Like Panic? A New Explanation. Journal of Money, Credit and Banking, 40, 535-546.

Choe, H, and Lee, B.S. (2003). Korean Bank Governance Reform After the Asian Financial Crisis. Pacific-Basin Finance Journal, 11, 483-508.

Diamond, D.W., and Dybvig, P.H. (1983). Bank Runs, Deposit Insurance, and Liquidity. Journal of Political Economy, 91, 401-419.

Dijk, O. (2017). Bank Run psychology. Journal of Economic Behavior $\mathcal{E}$ Organization, 144, 87-96.

Eckel, C.C., and Grossman, P.J. (2002). Sex Differences and Statistical Stereotyping in Attitudes toward Financial Risk. Evolution and Human Behavior, 23, 281295.

Ely, J. C. (2017). Beeps. American Economic Review, 107, 31-53.

Frederick, S., Loewenstein, G., and O'donoghue, T. (2002). Time Discounting and Time Preference: A Critical Review. Journal of economic literature, 40, 351-401.

Friend, I. (1977). The Demand for Risky Assets: Some Extensions. In Financial Dec Making Under Uncertainty, 65-82.

Gneezy, U., and Potters, J. (1997). An Experiment on Risk Taking and Evaluation Periods. The Quarterly Journal of Economics, 112, 631-645.

Goldstein, I., and Pauzner, A. (2005). Demand-Deposit Contracts and the Probability of Bank Runs. The Journal of Finance, 60, 1293-1327.

Kiss, H. J., Rodriguez-Lara, I., and Rosa-Garcia, A. (2018). Panic Bank Runs. Economics Letters, 162, 146-149.

Iyer, R., Puri, M. And Ryan, N. (2013). Do Depositors Monitor Banks? (No. w19050). National Bureau of Economic Research.

Jordan, J.S. (2000). Depositor Discipline at Failing Banks. New England Economic Review, 15.

Kashyap, A. K., Tsomocos, D. P., and Vardoulakis, A. (2017). Optimal Bank Regulation in the Presence of Credit and Run Risk.

Khwaja, A., Silverman, D., \& Sloan, F. (2007). Time Preference, Time Discounting, and Smoking Decisions. Journal of Health Economics, 26, 927-949.

Meier, S. And Sprenger, C. (2010). Present-biased Biased Preferences and Credit Card Borrowing. American Economic Journal: Applied Economics, 2, 193-210.

Morris, S., \& Shin, H. S. (2001). Rethinking Multiple Equilibria in Macroeconomic Modeling. Nber Macroeconomics Annual 2000, 139.

Nuryakin, C., \& Massie, N. W. G. (2018). Does Deposit Insurance Matter? Behavioral Evidence from Indonesia. Institute for Economic and Social Research.

Otoritas Jasa Keuangan (2015). Indonesia Banking Statistics (Statistik Perbankan Indonesia), 14.

Pathan, S., Skully, M. And Wickramanayake, J. (2008). Reforms in Thai Bank Governance: The Aftermath of the Asian Financial Crisis. International Review of Financial Analysis, 17, 345-362. 
Powell, M., \& Ansic, D. (1997). Gender Differences in Risk Behaviour in Financial Decision-Making: An Experimental Analysis. Journal of Economic Psychology, 18, 605-628.

Schotter, A. And Yorulmazer, T. (2009). On the Dynamics and Severity of Bank Runs: An Experimental Study. Journal of Financial Intermediation, 18, 217-241.

Schumacher, L. (2000). Bank Runs and Currency Run in A System without A Safety Net: Argentina and the Tequila'Shock. Journal of Monetary Economics, $46,257-277$. 